\title{
Tropical glacier meltwater contribution to stream discharge: a case study in the Cordillera Blanca, Peru
}

\author{
Bryan G. MARK, ${ }^{1 *}$ Geoffrey O. SELTZER ${ }^{2}$ \\ ${ }^{1}$ Max Planck Institute for Biogeochemistry, D-07745 Jena, Germany \\ E-mail:bmark@geog.gla.ac.uk \\ ${ }^{2}$ Department of Earth Sciences, Syracuse University, Syracuse, New York 13244, U.S.A.
}

\begin{abstract}
Discharge measurements, climate observations and hydrochemical samples gathered monthly (1998/99) in the Yanamarey and Uruashraju glacier-fed catchments of the Cordillera Blanca, Peru, permit an analysis of the glacier meltwater contribution to stream-flow. These glacier catchments feed the Río Santa, which discharges into the Pacific Ocean. Based on a water-balance computation, glacier melt contributes an estimated $35 \%$ of the average discharge from the catchments. For comparison, a volumetric end-member mixing model of oxygen isotopes shows glacier melt contributes $30-45 \%$ to the total annual discharge. Based on stream geochemistry, discharge from the Yanamarey glacier catchment provides $30 \%$ of the annual volume discharged from the Querococha watershed, which is $<10 \%$ glacierized. By analogy, the larger Río Santa watershed, also $<10 \%$ glacierized, receives at least $12 \%$ of its annual discharge from melting glacier ice. Tributary watersheds to the Río Santa with larger fractions of glacier cover have less variable runoff and enhanced discharge, demonstrating that the glaciers effectively buffer stream discharge seasonally. With continued glacier melting, stream-flow will likely become more variable, and there will be less dry-season runoff.
\end{abstract}

\section{INTRODUGTION}

The world's tropical glaciers have been retreating over the late 20th century, raising concerns about regional water supplies in alpine tropical regions (Hastenrath and Kruss, 1992; Francou and others, 1995b; Ribstein and others, 1995; Kaser, 1999). The consequence of sustained glacier retreat is the loss of glacier meltwater that provides a significant contribution to stream discharge, which is used for drinking water, hydroelectric power (HEP) generation and irrigation. If these glaciers disappear, there could be water-supply crises (Barry and Seimon, 2000). For example, a study of glacier mass balance has shown that $50 \%$ of the mean annual water discharge from Glaciar Yanamarey of the Cordillera Blanca, Peru, comes from net glacier mass loss due to retreat (Hastenrath and Ames, 1995). Under current rates of recession, Glaciar Yanamarey will disappear completely in half a century. Similarly, Glaciar Chacaltaya, Bolivia, could disappear within 10 years, causing an estimated $30 \%$ loss of stream discharge (Francou and others, 2000). However, it remains questionable if the results of these limited studies apply to discharge in larger valleys, such as the Río Santa, which drains $5000 \mathrm{~km}^{2}$ along the western slopes of the Cordillera Blanca (Fig. 1).

Another major concern is that the proportion of glacier melt contributing to stream discharge may vary seasonally in high-elevation tropical regions. Strongly seasonal precipi-

* Present address: Department of Geography and Topographic Science, University of Glasgow, Glasgow G12 8QQ Scotland. tation causes tropical glaciers to accumulate primarily in the wet season, when melting is also greatest. In the Cordillera Blanca, $70-90 \%$ of annual precipitation falls between October and March (Kaser and Georges, 1997). Ablation rates in the wet season are $33 \%$ greater than in the dry season (Kaser and others, 1990; Kaser, 1995). Seasonal increases in melting during the wet season are caused by changes in the vertical humidity gradient over the glacier surface, which alters the latent-heat flux and provides more energy to melt ice (Wagnon and others, 1999). However, this higher melt rate may not exceed the greater amount of precipitation received during the wet season that contributes to stream discharge. Consequently, a relatively greater proportion of glacier melt may contribute to stream discharge in the dry season than in the wet season.

This paper presents the results of work to evaluate the hydrological impact of glacier meltwater in the Cordillera Blanca at the scales of both small glacial catchments and the larger regional watershed of the Río Santa. Individual proglacial lakes are manageable settings for measuring the dynamics of the annual glacier-hydrological regime, whereas analyses of historical runoff data for larger glacierized tributary streams of the Río Santa address the impact of glacier melt to water supply at the regional scale.

\section{SETTING}

The tropical mountains of the Cordillera Blanca extend $120 \mathrm{~km}$ between $8.5^{\circ}$ and $10^{\circ} \mathrm{S}$ along a northwest-southeast strike, dividing stream runoff between the Pacific and Atlantic Oceans (Fig. 1). The largest percentage of glacierized area in the Cordillera Blanca discharges to the Pacific Ocean via the 


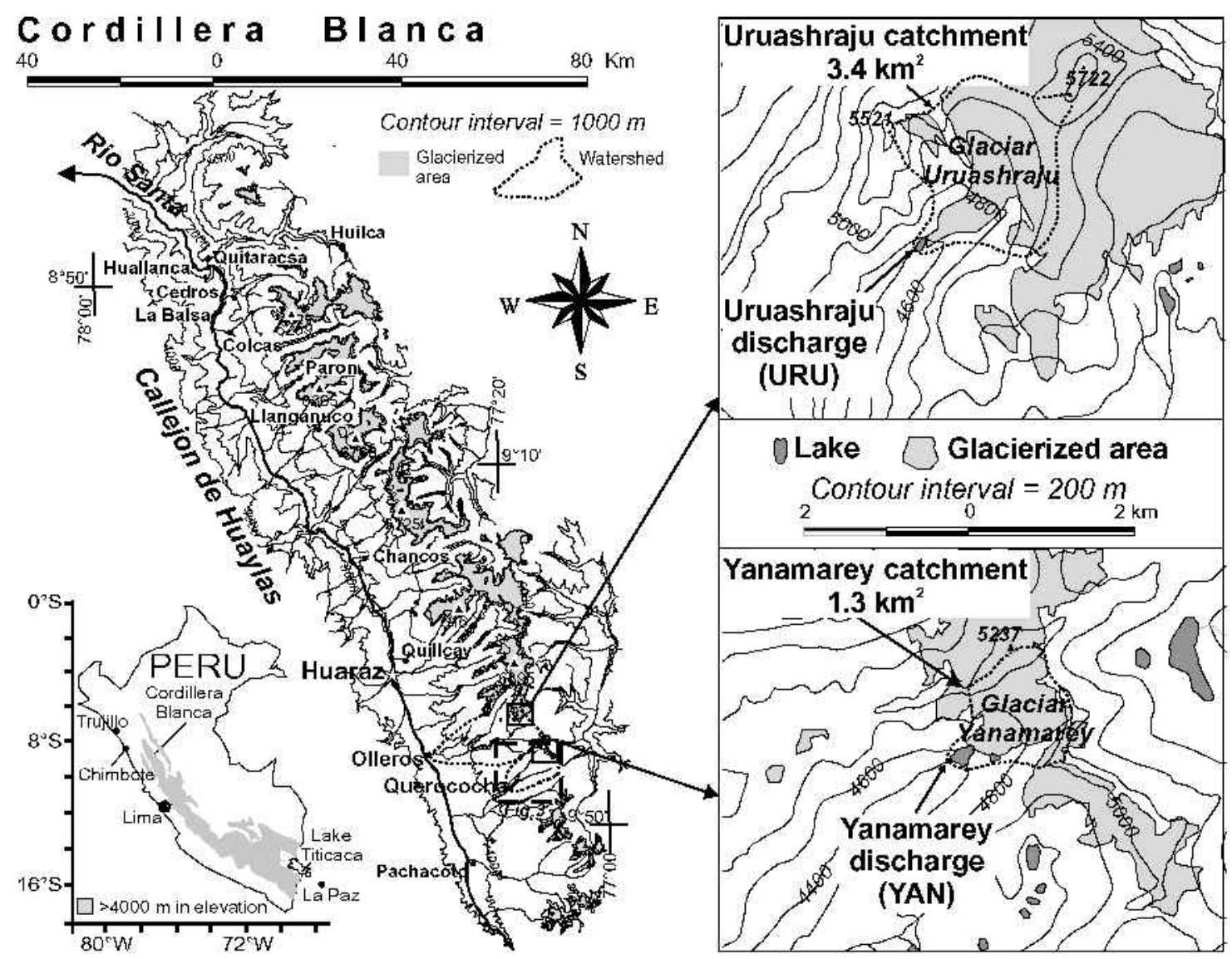

Fig. 1. Contour map of the Cordillera Blanca showing glacierized areas, the Rio Santa, the Glaciares Uruashraju and Yanamarey catchments (with enlargements), and stream gauge sites (solid circles) listed in Table 1. The larger Olleros and Querococha watersheds below the glacier catchments are outlined in dotted lines. A box with dashed outline shows the area covered by Figure 3.

Río Santa. Of the rivers draining to the Pacific coast of Peru, the Río Santa has the second largest discharge volume, but maintains the most regular flow, featuring the least variability in monthly runoff over the year. The Río Santa descends from $4300 \mathrm{~m}$ over $300 \mathrm{~km}$, draining a watershed of $12200 \mathrm{~km}^{2}$. Four hydroelectric plants along the lower canyon of the Río Santa supply power to mines and villages along its banks and to the port city Chimbote with its large steel mill and anchovy fishery industries. Other channels divert water from the river to irrigate large sugar plantations around the coastal city of Trujillo. The HEP plant at Huallanca $(1800 \mathrm{~m}$ a.s.l.) delimits the upper Río Santa watershed to an area of $4901 \mathrm{~km}^{2}$ that is referred to as the Callejon de Huaylas and is the focus of these studies.

The glacierized area contributing to Río Santa discharge varies among the tributary watersheds along the Callejon de Huaylas, although the Cordillera Blanca has undergone an overall reduction in glacier volume throughout the 20th century. The Glacier Inventory of Peru lists the total area of glaciers in the Cordillera Blanca as $723 \mathrm{~km}^{2}$, based on aerial

Table 1. Discharge data (from Egenor SA) and glacierized area for Río Santa tributary watersheds in the Callejon de Huaylas, west of the Cordillera Blanca

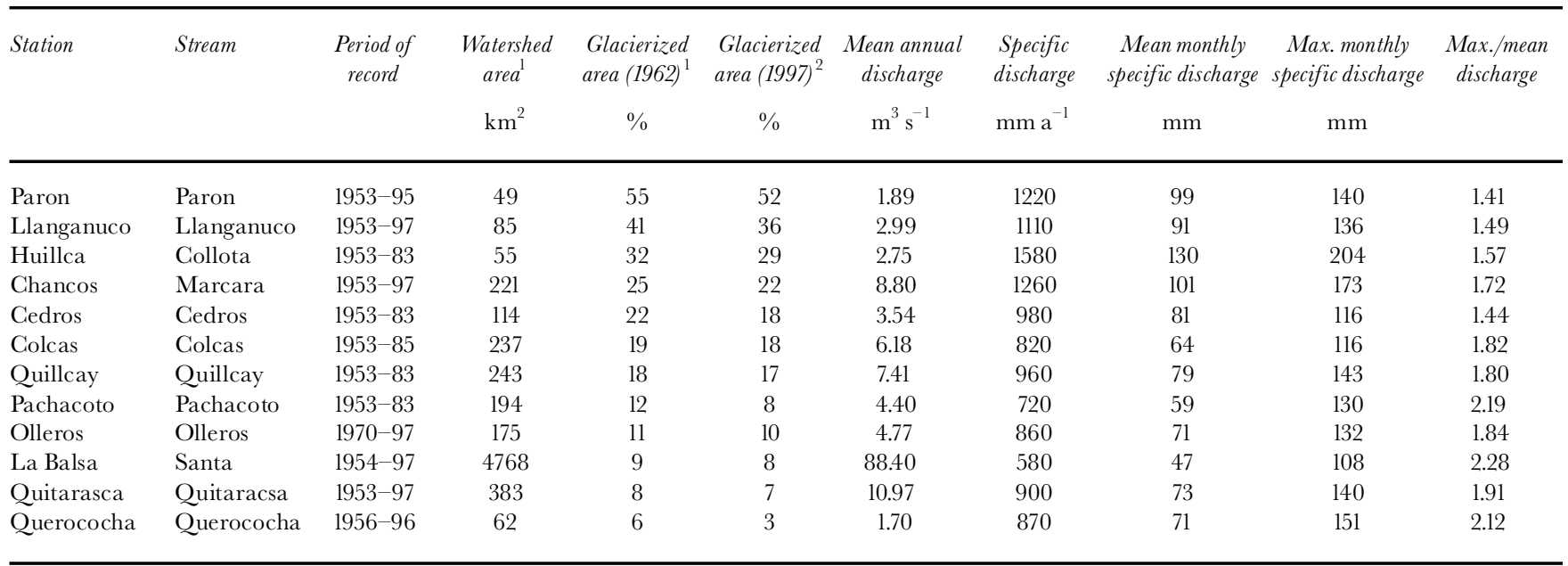

${ }^{1}$ Areas taken from 1: 100000 scale maps based on 1962 aerial photography. ${ }^{2}$ Areas taken from 1997 Landsat imagery. 


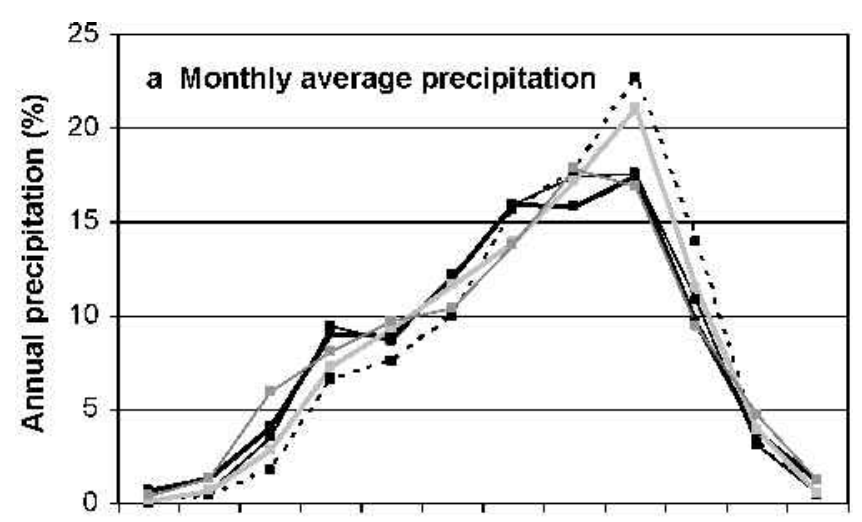

Jul Aug Sep Oct Nov Dec Jan Feb Mar Apr May Jun
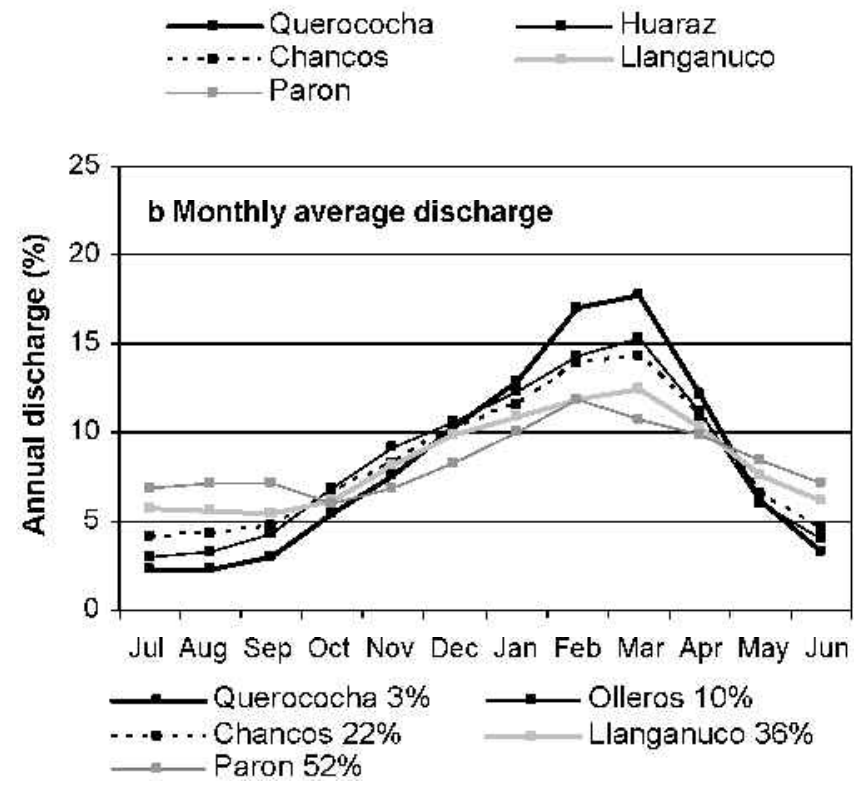

Fig. 2. (a) Mean monthly precipitation shown as percentage of the annual total for stations in the Callejon de Huaylas plotted over the hydrological year (July-June). (b) Mean monthly discharge for tributary streams of the Rio Santa, also shown as percentage of annual total, and plotted from Fuly to June. The percentage of glacierized area is also listed with each named tributary in the legend.

photography from 1962 and 1970, while monitoring of select glaciers has shown recession since a maximum position at the end of the 19th century (Kaser and Osmaston, 2002). The discharge of some tributary streams has been measured, and historical records are available for about 40 years (Table 1). Monthly average discharge from these gauged tributary streams entering the Callejon de Huaylas is higher during October-April, reflecting closely the highly seasonal annual cycle of precipitation typical of the outer tropics (Fig. 2). In contrast, the temperature remains relatively constant, and the annual variation of air temperature is smaller than the diurnal variation (Kaser and others, 1990). Larger-scale climatic features such as El Niño have also been shown to impact the interannual variability of temperature, precipitation and stream discharge in the tropical Andes (Francou and others, 1995a; Ribstein and others, 1995; Wagnon and others, 2001).

The individual glacier catchments selected for this case study drain to tributary streams of the Río Santa and contain Glaciares Yanamarey and Uruashraju, two small alpine glaciers located in the southern Cordillera Blanca (Fig. 1). The Yanamarey catchment covers $1.3 \mathrm{~km}^{2}$ between 4600 and
$5300 \mathrm{~m}$ a.s.l., $75 \%$ of which is covered by glacier ice. Runoff from the catchment flows to lake Querococha, and monthly discharge records from the lake effluent are available for the period 1956-96. The Uruashraju catchment covers $3.4 \mathrm{~km}^{2}$ over a slightly larger elevation range from 4600 to $5700 \mathrm{~m}$, and $65 \%$ of the area is covered by glacier ice. Runoff leaving this catchment joins a stream that flows past a gauge at Olleros, and monthly discharge records are available for the period 1970-97. The larger Olleros and Querococha watersheds containing the Uruashraju and Yanamarey catchments, respectively, are outlined in Figure 1.

The mouth of each glacier catchment is the outlet from a small proglacial lake that has formed in the bedrock in front of each glacier during recent glacier recession. The glacier catchments have very little vegetation (mosses and grasses) and poor soil development over the loosely consolidated alluvium and till. The bedrock in the region consists of metamorphosed sedimentary rocks (quartzite and hornfels), draping off the central granodioritic batholith that forms the core of the Cordillera Blanca (Wilson and others, 1967). Glacial meltwater entering the lakes is transmitted directly to the outlet streams without a significant lag due to lake storage. The abbreviations YAN and URU will be used henceforth to identify the Yanamarey and Uruashraju glacier catchments, respectively, and also label discharge sites at the outlet streams from the proglacial lakes (Fig. 1).

\section{DATA AND METHODS}

\subsection{Annual hydrology of the glacier catchments}

YAN and URU were visited monthly from May 1998 to August 1999 to collect observations of temperature and precipitation, and to measure stream discharge. Weather stations installed near the glacier termini in the 1980s contain totalizing rain gauges and mechanically recording thermographs installed in ventilated roofed shelters with a month-long storage capacity. Battery-powered Hobo temperature loggers (Onset Computer Corporation) installed in the covered shelters in 1998 sampled temperatures at $0.5 \mathrm{~h}$ intervals. Temperature data coverage extended from April 1998 through January 2000, with gaps due to mechanical failures of the thermographs and limited memory capacity in the data loggers. Stream discharge was calculated using the crosssectional averaging technique (Mosley and McKerchar, 1993) at the streams discharging from the proglacial lakes below each glacier terminus. Velocity was measured with a mechanical flow meter (Model 2030R, General Oceanics Inc.).

A basic water-balance model holds that the total volume of water discharging from a catchment is equal to the volume of water entering the catchment plus a change in storage. In this case study, it is assumed that the primary outflow consists of the total discharge leaving the proglacial lake $\left(Q_{\mathrm{t}}\right)$, whereas the only input is precipitation $(P)$ falling over the watershed area. Losses from the system include evaporation and/or sublimation $(E)$ and ground-water recharge $(\mathrm{Gw})$. The change in storage is considered to be a loss or gain of glacier ice volume $(\Delta g)$, where a loss (negative $\Delta g$ ) of glacier volume contributes positively to $Q_{\mathrm{t}}$. Thus the final balance is:

$$
Q_{\mathrm{t}}=P-E-\mathrm{Gw}-\Delta g .
$$

Measurements of $Q_{\mathrm{t}}\left(\mathrm{m}^{3} \mathrm{~s}^{-1}\right)$ are converted to a depth measure $(\mathrm{mm})$ to compare with linear measurements of the 
other variables by multiplying by the number of seconds in the respective interval of time between measurements (approximately 1 month), and normalizing by the area of the glacier watershed as determined from a digital elevation model of the area. Likewise, $P$ is a total depth falling between the same measurement dates. Because the glacier watersheds consist primarily of relatively impermeable bedrock, loss to the ground-water system is not considered significant. The water balance can be simplified and rearranged to consider the glacial meltwater contribution to stream discharge as the change in the storage term $(\Delta g)$ :

$$
\Delta g=P-E-Q_{\mathrm{t}} .
$$

A lack of empirical data in this study precludes explicit monthly quantification of $E$. Generally, $E$ is small compared to others in glacier watershed balance equations. Yet a recent study in the tropical Bolivian Andes has shown that sublimation accounts for about $17 \%$ of the total annual mass loss from a glacier (Wagnon and others, 1999). Two calculations of the hydrologic budget were made in this study to estimate the magnitude of potential change in glacier volume. First, $E$ is assumed negligible, and set equal to zero, so that the change in storage is assumed to be entirely composed of glacier melt or accumulation. A second calculation was also made, considering that loss by $E$ from the watershed adds proportionately to the glacier melt component of the total annual change in storage. This effectively increases the absolute value of $\Delta g$; more ice volume is required to be removed from the watershed to account for evaporative/sublimation loss while $Q_{\mathrm{t}}$ and $P$ remain the same. Since the climate is similar but drier in the tropical Bolivian Andes, $20 \%$ of the total annual loss is considered a conservative estimate of evaporation here based on the results from the tropical study cited above. Thus, the change in storage assumed here in case one to be entirely glacier melt is in the second case equal to only $80 \%$ of a larger potential total change in storage when $E$ is considered.

\subsection{Hydrochemistry of glacial and non-glacial streams}

During the monthly visits to the glacial watersheds, water was sampled at the stream-discharge measuring sites below each glacier (Fig. 1), as well as at three additional sites below YAN within the Querococha watershed (Fig. 3). Two separate water samples were taken at each site in plastic Nalgene bottles for solute and isotopic measurements. $50 \mathrm{~mL}$ of sample were filtered through a $47 \mu \mathrm{m}$ glass-fiber filter for the solute analyses. $25 \mathrm{~mL}$ samples were also collected for isotopic analysis by completely submerging and sealing the vials under the water surface. The bottle caps were then sealed with tape to prevent leakage and evaporation, and samples were stored in an enclosed cabinet for up to 4 months before being transported to chilled $\left(4^{\circ} \mathrm{G}\right)$ laboratory storage. Laboratory analyses were completed at Syracuse University during September 1999.

Direct-current plasma spectroscopy (Beckman Spectraspan-V) was used to analyze for $\mathrm{Ca}^{2+}, \mathrm{Na}^{+}, \mathrm{Fe}^{3+}, \mathrm{Si}^{+}, \mathrm{Mg}^{2+}$, $\mathrm{Sr}^{2+}$ and $\mathrm{K}^{+}$. Concentrations of $\mathrm{SO}_{4}{ }^{2-}, \mathrm{Cl}^{-}$and $\mathrm{NO}_{3}{ }^{-}$were measured using ion chromatography with a Dionex DX500 chromatography system. Carbonate alkalinity (sum of charged carbonate species, $\mathrm{CO}_{3}{ }^{2-}$ and $\mathrm{HCO}_{3}{ }^{-}$) was calculated as a residual from the charge balance equation (Drever, 1997). Values of $\delta^{18} \mathrm{O}$ and $\delta \mathrm{D}$ were measured with a mass spectrometer (Finnigan MAT 252 directly coupled to a

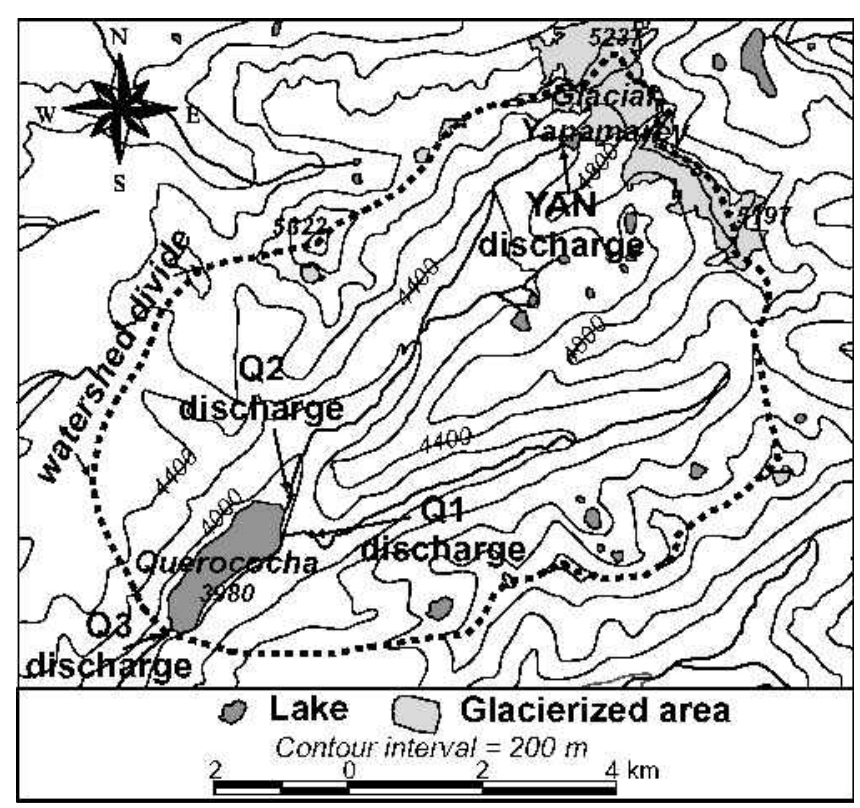

Fig. 3. Map of the lake Querococha watershed, showing the discharge- and water-sampling points: $\Upsilon A \mathcal{N}$, proglacial lake discharge; Q1, non-glacier stream; Q2, downstream of $Y A \mathcal{N}$; Q3, discharge from lake Querococha.

HDO II water equilibrator), and reported relative to the Vienna Standard Mean Ocean Water (V-SMOW) standard, with an accuracy of $\pm 0.1 \%$ for $\delta^{18} \mathrm{O}$ and $\pm 3 \%$ for $\delta \mathrm{D}$.

A two-component mixing model incorporates isotope values to estimate the volume of glacier meltwater added to precipitation-generated discharge at YAN (Clark and Fritz, 1997). The total discharge at YAN $\left(Q_{\mathrm{t}}\right)$ is considered a mixture of precipitation $\left(Q_{\mathrm{p}}\right)$ and glacier melt $\left(Q_{\mathrm{m}}\right)$ :

$$
Q_{\mathrm{t}}=Q_{\mathrm{p}}+Q_{\mathrm{m}} \text {. }
$$

These discharge volumes can be combined with the stableisotope values for each mixing component to derive a volume-weighted isotopic mass balance such that

$$
\delta_{\mathrm{t}} Q_{\mathrm{t}}=\delta_{\mathrm{p}} Q_{\mathrm{p}}+\delta_{\mathrm{m}} Q_{\mathrm{m}},
$$

where $\delta_{\mathrm{t}}, \delta_{\mathrm{p}}$ and $\delta_{\mathrm{m}}$ refer to the $\delta^{18} \mathrm{O}$ value of the proglacial lake, precipitation and glacier melt, respectively. This equation can be rearranged and solved for the volume of glacier melt, given measured or estimated $\delta^{18} \mathrm{O}$ values. As described above, both $Q_{\mathrm{t}}$ and $Q_{\mathrm{p}}$ were measured directly each month. The stable-isotope values of proglacial lake water $\left(\delta_{\mathrm{t}}\right)$ were also measured directly during each month of sampling. Many factors, such as elevation, temperature and evaporation, contribute to alter the isotopic value of glacier ice subject to melting, so the isotopic value of the glacier melt component is expected to vary (Stichler and Schotterer, 2000; He and others, 2001). A value of $-14.5 \pm 2.3 \%$ was used for the melted glacier ice $\left(\delta_{\mathrm{m}}\right)$, based on the average and standard deviation of five melted glacier ice and firn samples. Without a reliable method to collect precipitation samples for isotopic analyses, mean monthly measurements from La Paz, Bolivia, (16 ${ }^{\circ} 17^{\prime} \mathrm{S}, 68^{\circ} 5^{\prime} \mathrm{W}$; $4071 \mathrm{~m}$ a.s.l.) were used. La Paz is the nearest Andean station with available stable-isotope data, with records covering the period 199597 (International Atomic Energy Agency (IAEA) and World Meteorological Organization (WMO) global network for isotopes in precipitation, http://www.iaea.org/ programs/ri/gnip/gnipmain.htm), and it also has a similar 


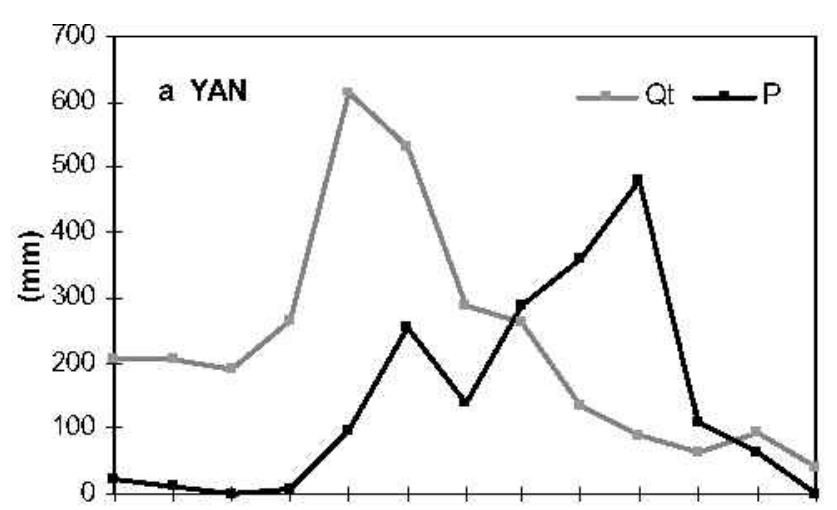

08- 06- 10- 19 - 19- 28- 29- 04- 05- 23- 02- 25- $01-$ Jun- Jul- Aug- Sep- Oct- Nov-Dec-Feb-Mar- Apr- Jun- Jun- Aug$\begin{array}{lllllllllllll}98 & 98 & 98 & 98 & 98 & 98 & 98 & 99 & 99 & 99 & 99 & 99 & 99\end{array}$

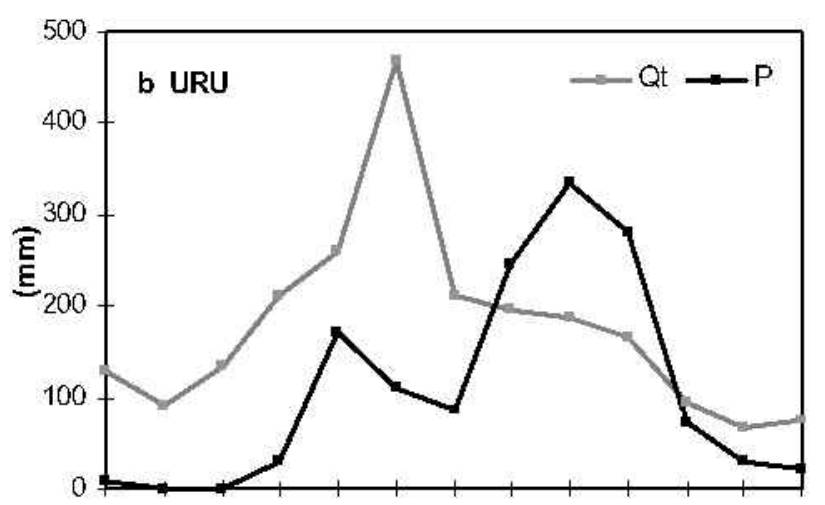

24- 24- 29- 04- 31- 29- 21- 28- 07- 25- 25- 26- 26Jun- Jul- Aug- Oct- Oct- Nov-Dec- Jan- Mar- Apr- May- Jun- Jul$\begin{array}{lllllllllllll}98 & 98 & 98 & 98 & 98 & 98 & 98 & 99 & 99 & 99 & 99 & 99 & 99\end{array}$

Fig. 4. Monthly measurements of discharge $\left(Q_{\mathrm{t}}\right)(\mathrm{mm})$ plotted with the monthly precipitation totals $(P)(\mathrm{mm})$ as observed over the 1998/99 hydrological year for (a) MAN and (b) URU.

annual variability in precipitation. The mean monthly values provided the stable-isotope values of precipitation $\left(\delta_{\mathrm{p}}\right)$ in the mixing model, and the standard deviation of the monthly values provided a range in the computed value of $Q_{\mathrm{m}}$.
A second mixing model estimates the proportion of glacier melt from YAN contributing to discharge from lake Querococha based on the concentrations of cations and anions, following the procedures outlined by Hounslow (1995). The chemical composition of a mixture of two waters lies along a straight line in the Piper diagram joining the two end-member compositions (Piper, 1944). The relative amount of each end member contributing to the mixture is inversely proportional to the distance along the line from the end member.

\section{RESULTS}

\subsection{Annual hydrology of the glacier catchments}

Within the glacier catchments, $P$ and $Q_{\mathrm{t}}$ show an offset in respective maxima that is distinct from the general pattern seen in larger watersheds downstream. Maximum $Q_{\mathrm{t}}$ precedes the peaks in average $P$ by $2-4$ months (Fig. 4 ). A lack of available data for the Olleros and Querococha watersheds for the period of study precludes a simultaneous comparison with the glacier catchments, so the trend of mean monthly values over the historical period of observation is used to characterize the larger watersheds. Mean discharge is closely correlated in time to mean $P$ in the larger watersheds, as illustrated by the time series for Querococha and Olleros, located downstream of YAN and URU, respectively (Table 2; Fig. 5). Within the glacier catchments, $Q_{\mathrm{t}}$ does not correlate well with $P$, but is equally poorly correlated with both temperature and $P$ (Table 2).

The hydrologic balance of the glacier watersheds calculated monthly (Equation (2)) yields the change in storage term $(\Delta g)$, which provides an estimate of the mean monthly contribution of glacier melt to stream discharge (Fig. 6). Positive values of $\Delta g$ represent storage gain (net accumulation), and diminish $Q_{\mathrm{t}}$, while negative values represent storage loss (net melt) and an enhancement of $Q_{\mathrm{t}}$. The plot of $\Delta g$ shows that the maximum in specific melt $(\mathrm{mm})$ occurs in October and November for Glaciares Yanamarey and Uruashraju. However, glacier melt contributes a maximum relative percentage of the monthly $Q_{\mathrm{t}}$ during the dry-season

Table 2. Mean monthly discharge $(Q)$ in mm, precipitation $(P)$ in $m m$, and temperature $(T)$ in ${ }^{\circ} \mathrm{C}$ for different stations in the Cordillera Blanca and the glacier catchments. The number of years available to calculate each mean monthly variable is listed. Linear correlation coefficients (Pearson's product moment, $r$ ) are calculated for correlations between discharge and precipitation and discharge and temperature for each station

\begin{tabular}{|c|c|c|c|c|c|c|c|c|c|c|c|c|c|c|}
\hline Station & Number of years & June & fuly & Aug. & Sept. & Oct. & Nov. & Dec. & Jan. & Feb. & Mar. & $A p r$ & May & Pearson's (r) \\
\hline Querococha $Q$ & 40 & 28 & 19 & 19 & 26 & 48 & 64 & 90 & 113 & 134 & 154 & 102 & 54 & \\
\hline$\widetilde{Q u e r o c o c h a} P$ & 40 & 12 & 7 & 13 & 40 & 89 & 88 & 118 & 156 & 154 & 171 & 94 & 37 & 0.94 \\
\hline Querococha $T$ & 40 & 7.5 & 7.3 & 7.7 & 7.6 & 7.5 & 7.7 & 7.6 & 7.5 & 7.3 & 7.3 & 7.6 & 7.7 & 0.41 \\
\hline Olleros $Q$ & 27 & 34 & 27 & 29 & 37 & 61 & 78 & 94 & 109 & 115 & 137 & 95 & 53 & \\
\hline Huaraz $P$ & 40 & 3 & 1 & 5 & 23 & 62 & 57 & 80 & 104 & 113 & 115 & 71 & 20 & 0.96 \\
\hline Hurarz $T$ & 40 & 15 & 14.5 & 15.2 & 15.5 & 15.3 & 15.3 & 15.3 & 15.1 & 15.1 & 15 & 15.3 & 15.4 & 0.52 \\
\hline YAN $Q$ & 1 & 208 & 206 & 190 & 265 & 614 & 531 & 289 & 263 & 134 & 113 & 91 & 64 & \\
\hline YAN $P$ & 15 & 11 & 34 & 100 & 148 & 154 & 174 & 217 & 252 & 244 & 147 & 61 & 18 & 0.54 \\
\hline YAN $T$ & 12 & 2.4 & 1.8 & 1.8 & 2.5 & 2.9 & 2.7 & 2.9 & 1.9 & 1.9 & 2 & 2.5 & 2.6 & 0.70 \\
\hline URU $Q$ & 1 & 128 & 91 & 134 & 210 & 259 & 467 & 212 & 196 & 186 & 176 & 167 & 94 & \\
\hline URU $P$ & 11 & 10 & 13 & 59 & 108 & 118 & 119 & 207 & 191 & 189 & 139 & 43 & 22 & 0.51 \\
\hline URU T & 9 & 2.7 & 2.4 & 2.2 & 2.4 & 2.9 & 2.7 & 2.4 & 2.3 & 2.3 & 1.9 & 2.1 & 2.1 & 0.54 \\
\hline
\end{tabular}




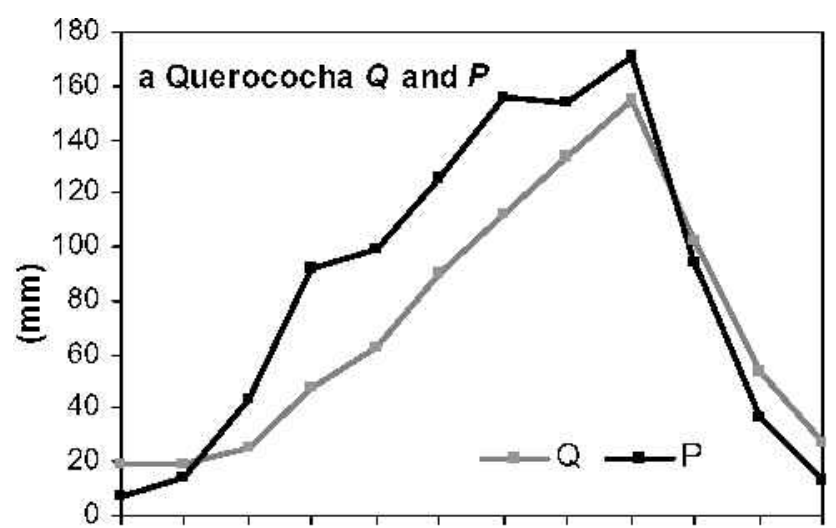

Jul Aug Sep Oct Nov Dec Jan Feb Mar Apr May Jun

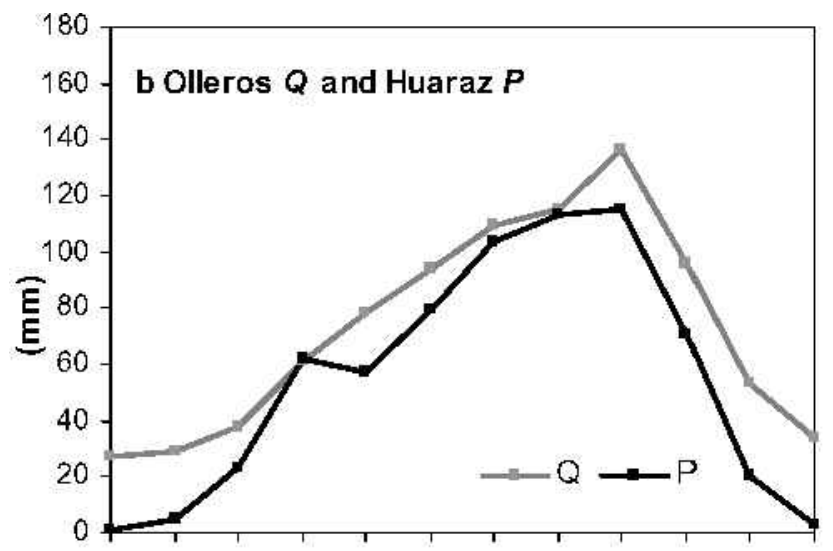

Jul Aug Sep Oct Nov Dec Jan Feb Mar Apr May Jun

Fig. 5. Mean monthly discharge $(Q)(\mathrm{mm})$ and precipitation $(P)(\mathrm{mm})$ plotted for $(a)$ the Querococh a watershed, downstream of $Y A \mathcal{N}$, representing the average of 40 years for both variables; and (b) the Olleros watershed, downstream of $U R U$, representing the average of 27 years of discharge data and 40 years of precipitation data from nearby Huaraz.

months (June-September). During this period of little to no precipitation, glacier melt contributes up to $100 \%$ of $Q_{\mathrm{t}}$. Yet over the course of the wet season, $\Delta g$ shifts dramatically from storage release to storage accumulation.

The total annual volume of glacier meltwater is expressed as a discharge, and also as a percentage of the average annual stream discharge (Table 3). Assuming that the loss in storage is exclusively by melting, then glacier ice loss comprises 35\% of the total annual stream discharge in YAN and $36 \%$ of total discharge in URU. If $20 \%$ of the total storage is lost to evaporation/sublimation (e.g. Wagnon and others, 1999), a larger total volume of ice loss would have to be ablated annually, equivalent to about $44 \%$ of the total discharge in YAN, and $45 \%$ in URU.

\subsection{Hydrochemistry of glacial and non-glacial streams}

The $\delta^{18} \mathrm{O}$ values of the stream waters conform closely to the meteoric water-line, and follow a pattern of annual variation similar to the isotope values of precipitation measured at the IAEA station in La Paz (Fig. 7). The monthly isotope measurements show a maximum value in October-November and a minimum value in March-April. The precipitation $\delta^{18} \mathrm{O}$ varies by $\sim 10 \%$ o between a maximum in October and minimum in April, which is a greater magnitude of annual change than the stream waters. The average isotopic values
Table 3. Amount of glacier meltwater ( $\mathrm{mm}$ ) and relative contribution to average annual stream discharge ( $\%$ aver $Q$ ) for the glacier catchments

\begin{tabular}{lccc}
\hline Catchment & Area & Glacier melt & Contribution \\
& $\mathrm{km}^{2}$ & $\mathrm{~mm}$ & $\%$ aver $Q$ \\
\hline YAN & 1.3 & $970(1210)$ & $35(44) \pm 10$ \\
URU & 3.4 & $780(975)$ & $36(45) \pm 10$ \\
\hline
\end{tabular}

Notes: Values in parentheses represent larger potential estimates assuming $20 \%$ annual glacier ablation is due to evaporation and/or sublimation. A $10 \%$ range is approximated assuming $10 \%$ error in stream-discharge measurement and $5 \%$ in precipitation measurement.

are lowest in the glacier catchments (YAN, URU), but show a higher variability over the year than the other stream samples. Isotopic variability of stream water varies with the size of the watershed and with the relative amount of glacier runoff contribution. There is a downstream decrease in the magnitude of annual isotope variability $\left(\Delta \delta^{18} \mathrm{O}\right)$ among the stream samples, with samples from the proglacial lake discharge YAN showing 9\%o change over the year and those from site Q3 at the outlet of Querococha showing only

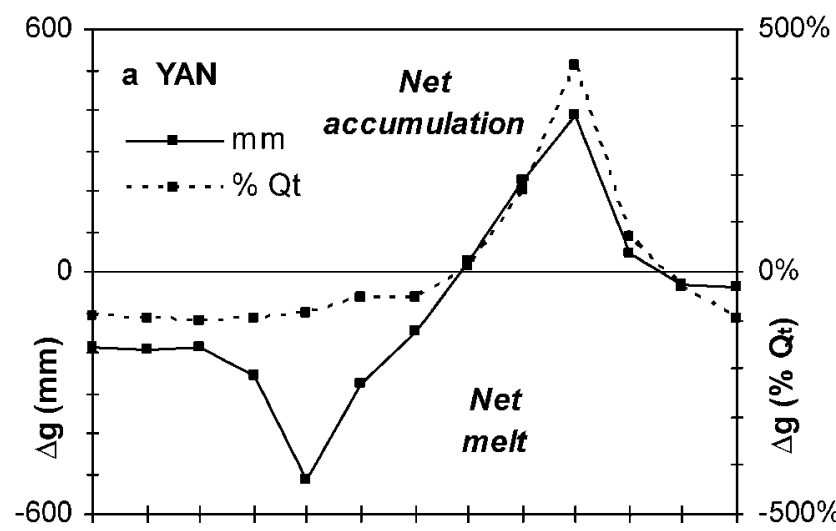

08- 06- 10- 19- 19- 28- 29-04- 05- 23- 02- 25- 01 Jun-Jul-Aug-Sep-Oct-Nov-Dec-Feb-Mar-Apr-Jun-Jun-Aug$\begin{array}{lllllllllllll}98 & 98 & 98 & 98 & 98 & 98 & 98 & 99 & 99 & 99 & 99 & 99 & 99\end{array}$

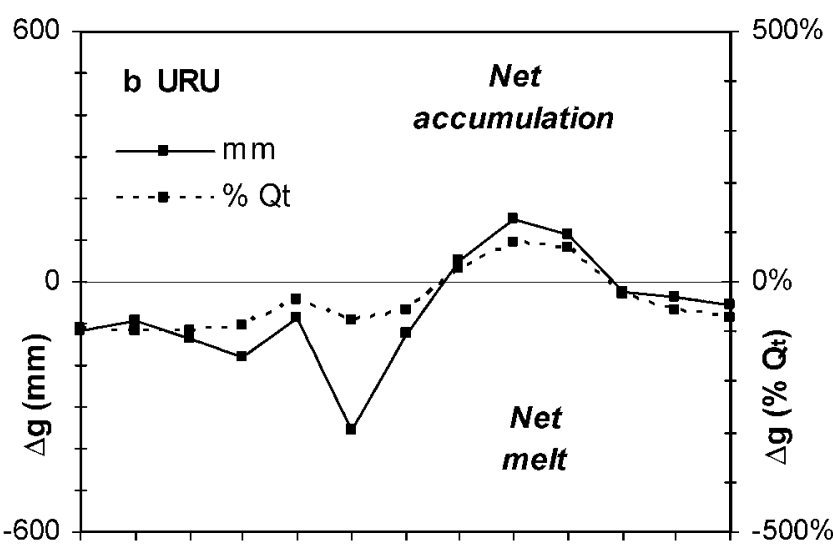

24- 24- 29- 04- 31- 29- 21- 28- 07- 25- 25- 26- 26Jun- Jul-Aug-Oct-Oct-Nov-Dec-Jan-Mar-Apr-May-Jun- Jul$\begin{array}{lllllllllllll}98 & 98 & 98 & 98 & 98 & 98 & 98 & 99 & 99 & 99 & 99 & 99 & 99\end{array}$

Fig. 6. Change in glacier storage volume $(\Delta g)$, expressed both in $\mathrm{mm}$ and as a percentage of monthly stream discharge leaving the proglacial lake $\left(Q_{\mathrm{t}}\right)$, calculated for (a) TAN and (b) URU. 

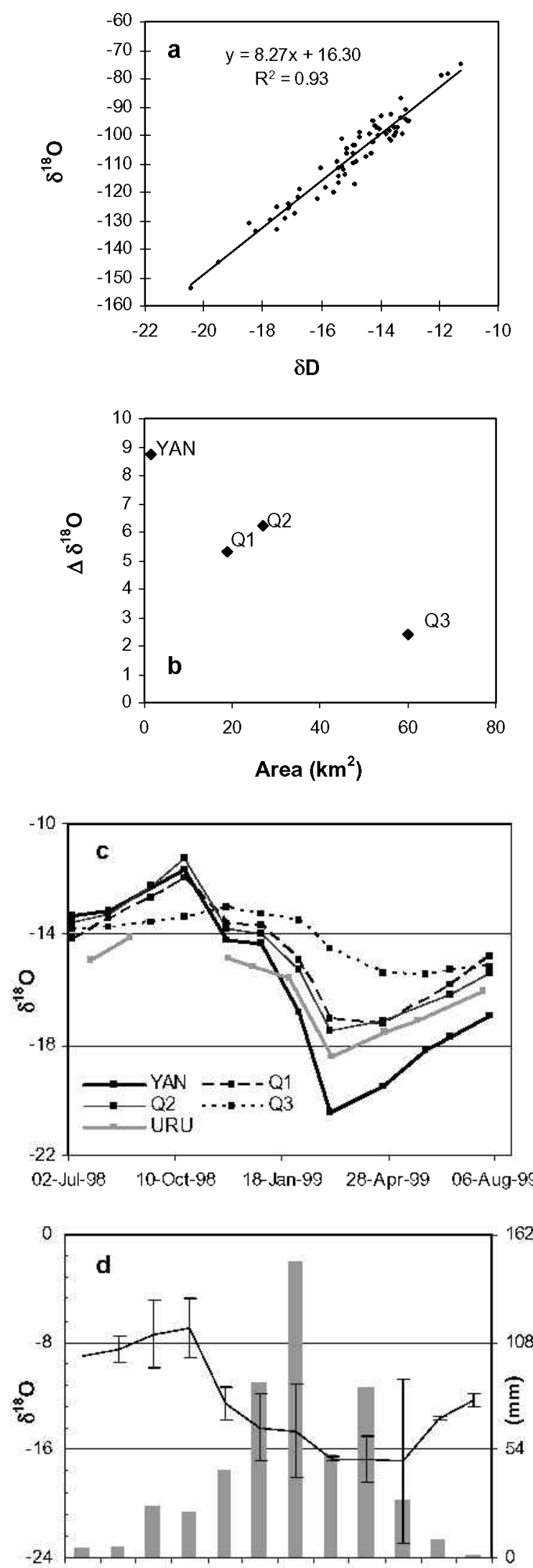

Jul Aug Sep Oct Nov Dec Jan Feb Mar Apr May Jun

Fig. 7. Isotopic data used: (a) local meteoric water-line drawn through bivariate plot of all stream samples from the Querococha watershed; (b) annual range of isotopic values $\left(\Delta \delta^{18} O\right)$ as a function of watershed area for each sample site; (c) time series of $\delta^{18} \mathrm{O}$ for each stream sample over the 1998/99 hydrological year; (d) mean monthly precipitation (bars) and $\delta^{18} \mathrm{O}$ values for $\mathrm{La} \mathrm{Paz}(4071 \mathrm{~m}$ ) averaged over the existing years of IAEA data, 1995-97, with error bars showing the standard deviation of monthly isotopic values.

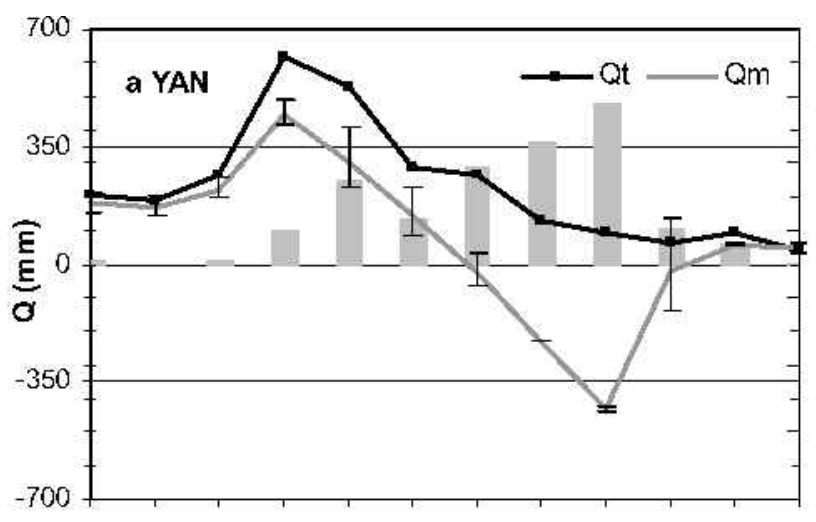

06- 10- 19- 19- 28- 29- 04- 05- 23- 02- 25- 01 Jul- Aug- Sep- Oct- Nov- Dec- Feb- Mar- Apr- Jun- Jun- Aug$\begin{array}{llllllllllll}98 & 98 & 98 & 98 & 98 & 98 & 99 & 99 & 99 & 99 & 99 & 99\end{array}$

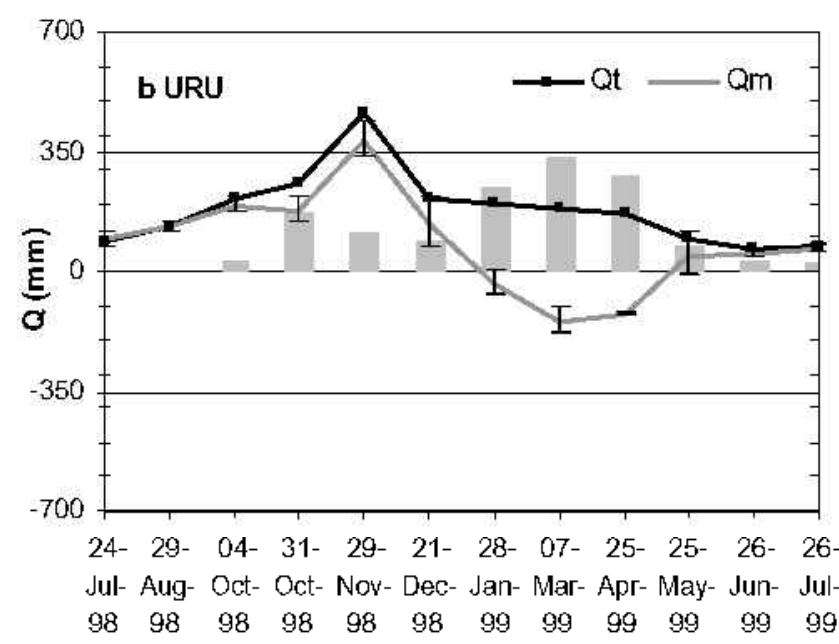

Fig. 8. Results of a two-component isotopic mixing model during the months with stream sample data over the 1998/99 hydrological year, showing the discharge due to glacier melt $\left(Q_{\mathrm{m}}\right)$ and total discharge from the proglacial lake $\left(Q_{\mathrm{t}}\right)$ for (a) YAN and (b) URU. Discharge from precipitation is shown with bars. The error bars reflect variability of isotopic values for precipitation and glacier melt.

$\sim 2 \%$ annual variation. The slightly higher variability at site Q2 than Q1 reflects the glacier melt contribution.

The isotopic mixing model predicts that the discharge from melting glacier ice $\left(Q_{\mathrm{m}}\right)$ has an annual variation similar to that calculated from the hydrological balance (Fig. 8). There is maximum $Q_{\mathrm{m}}$ in October-November as well as maximum glacier storage during March-April. When summed over the hydrologic year, the total volume of $Q_{\mathrm{m}}$ can be expressed as a percentage of the total $Q_{\mathrm{t}}$ to estimate the total annual contribution from glacier ice melt. This is best presented as a range, accounting for the variation in monthly isotope values of precipitation. Glacier melt accounts for $31 \%$ of the proglacial lake discharge volume at YAN and $45 \%$ at URU based on the isotope values.

The averaged concentrations of major anions and cations from each stream sample site over the hydrologic year (Table 4) form a mixing line when plotted on a Piper diagram (Fig. 9). The concentrations from YAN and the non-glacier stream Q1 sites form the two end points of the mixing line. The mixed member coming from Querococha, Q3, falls at a distance inversely proportional to the concentration of each end-member contribution, such that $30 \%$ is derived from YAN and 70\% from the non-glacier stream Q1. 
Table 4. Average major-ion composition (in $\mu$ eq $L^{-1}$ ) for sites in the Querococha watershed

\begin{tabular}{lccccccc}
\hline Site & $\mathrm{Ca}^{2+}$ & $\mathrm{Mg}^{2+}$ & $K^{+}$ & $\mathrm{Na}^{+}$ & $\mathrm{Cl}$ & $\mathrm{SO}_{4}^{2-}$ & $\mathrm{HCO}_{3}^{-}$ \\
\hline $\mathrm{YAN}$ & 589 & 114 & 12 & 70 & 2 & 955 & $\mathrm{n} / \mathrm{a}$ \\
$\mathrm{Q} 1$ & 349 & 51 & 11 & 137 & 8 & 188 & 397 \\
$\mathrm{Q} 2$ & 397 & 80 & 11 & 57 & 3 & 567 & 91 \\
$\mathrm{Q} 3$ & 343 & 56 & 12 & 70 & 2 & 39 & 112 \\
\hline
\end{tabular}

On the larger scale of the tributaries to the Callejon de Huaylas, where stream discharge is closely tied to the annual cycle of precipitation, the magnitude and variability of discharge are directly related to the percentage of glacier coverage (Fig. 10). The magnitude of specific discharge (average annual stream discharge normalized by watershed area) generally increases with larger amounts of glacier coverage. Annual stream discharge is also less variable in watersheds with larger glacierized areas, as illustrated by the ratio of maximum discharge to mean discharge as a function of the percentage of glacier coverage.

\section{DISGUSSION}

\subsection{Hydrological balance methods}

Utilizing a simplified hydrologic balance to estimate glacier mass balance is justified here based on a lack of surface-based observations, but involves many complications (e.g. Fountain and others, 1999). Without energy-balance measurements and restricted to single precipitation gauges in each catchment, we were unable to quantify important issues of spatially variable precipitation inputs and evaporation. Also, the total change in storage considered for the glacier watersheds actually contains long-term storage of water coming

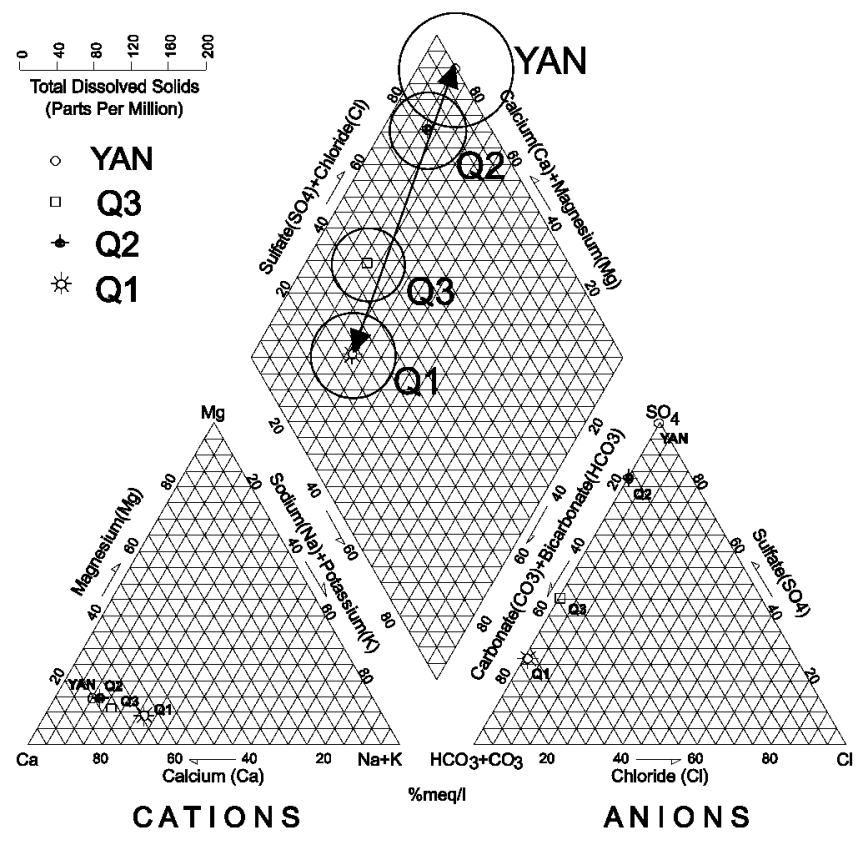

Fig. 9. Piper plot of mean monthly chemistry concentrations for the stream sites within the Querococha watershed. The radii of the circles represent total dissolved solids in parts per million according to the included scale.
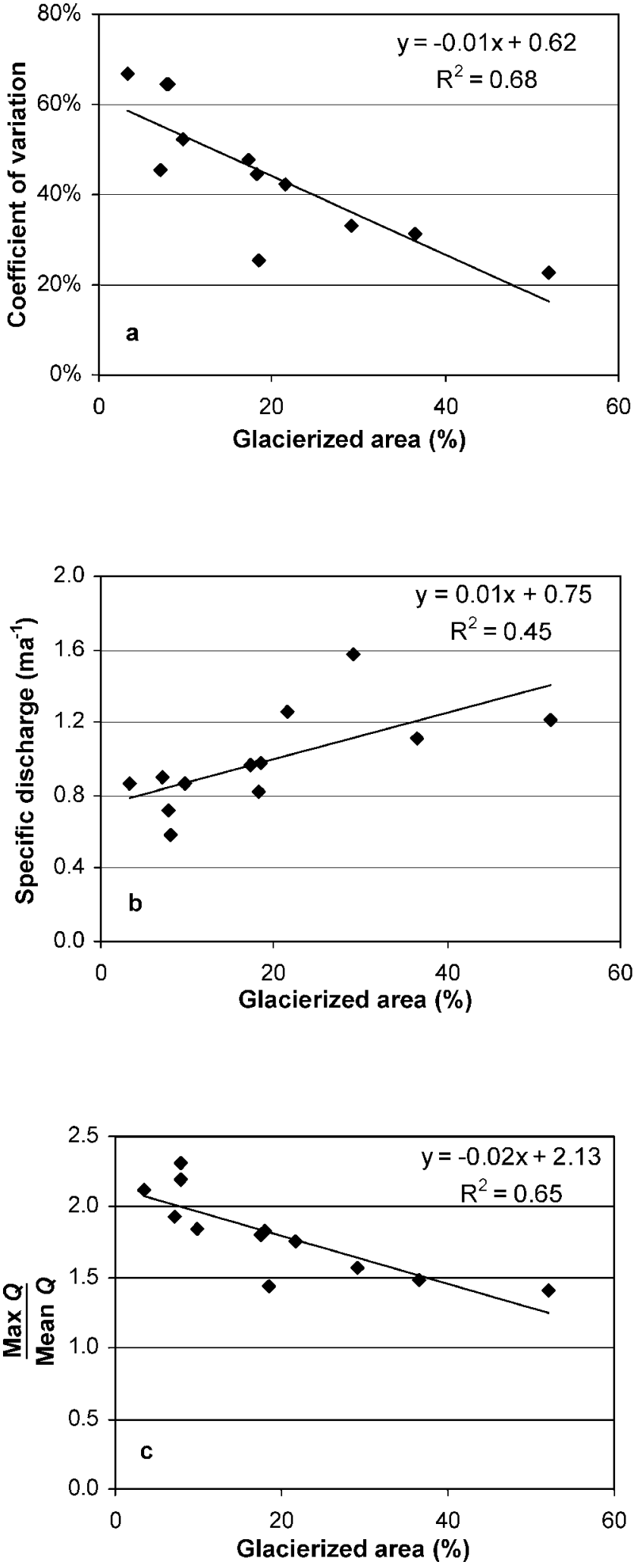

Fig. 10. Magnitude and variation of annual stream discharge with percentage of glacierized area in the Río Santa tributaries, shown by (a) coefficient of variation $(\%) ;(b)$ specific discharge $\left(\mathrm{ma}^{-1}\right)$; (c) ratio of maximum monthly discharge to mean monthly discharge $(\max Q /$ mean $Q)$.

from glacier ice, firn and snow. Much work has been devoted to investigating the seasonal patterns of meltwater storage in glaciers in different extratropical regions (e.g. Tangborn and others, 1975; Östling and Hooke, 1986; Hodgkins, 2001), and further investigation differentiating the impact of seasonal storage should be conducted on tropical glaciers. 
The use of simplified mixing models based on the solute chemistry of meltwater has been well established in glacier hydrology as a method to separate subglacial and englacial components of discharge (e.g. Collins, 1978). The method is not without problems, and the assumption that the end members mix conservatively is especially problematical within the glacier environment (Sharp and others, 1995). Rather than deciphering members of englacial and subglacial waters routing through a glacier, this study focuses on the fate of waters leaving from the glacier catchment and mixing downstream. The simplified mixing-model assumptions are justified to make some first-order quantitative estimates of meltwater impact on stream discharge given the lack of any other data.

\subsection{Seasonality of tropical meltwater}

The discrepancy in timing between maximum stream discharge and maximum precipitation within the Yanamarey and Uruashraju glacier catchments documents an important seasonal variation in the hydrological balance of these tropical glaciers. Previous research on tropical glaciers suggested that the maximum discharge from the glaciers occurs at the peak of the wet season, when both accumulation and ablation reach maximum levels (e.g. Kaser, 1999). However, the lack of correlation between peak precipitation and peak discharge shown here implies a change in glacier storage over the hydrological year. The early months of the wet season (October-November) produce net glacier loss, associated with maximum discharge, whereas the later months of the wet season (January-March) result in net accumulation of mass, as discharge decreases and precipitation levels continue to rise. Given the inconsistencies in the length of time series for the different spatial scales compared (1 year at the glacier catchment scale compared to 27 and 42 years at the Olleros and Querococha watersheds, respectively), these results defy rigorous quantitative comparison. Nevertheless, they provide important evidence that is substantiated by other research on the seasonal energy balance of tropical glaciers.

The tropical climate during maximum glacier discharge is conducive to melting ice, emphasizing the hydrological significance of these transitional months between the late dry and early wet seasons. Previous work on Glaciar Zongo, Bolivia (Francou and others, 1995b; Ribstein and others, 1995; Wagnon and others, 1999), and ongoing work on both Bolivian and Ecuadorian glaciers (Francou and others, 2000) show that this is a period that features both minimum surface reflectivity (albedo) after the dry season and increased atmospheric humidity, which cause more energy to be available to melt glacier ice. Total net radiation is the primary source of energy to the glacier surface, and a surface that is less reflective (lower albedo) absorbs more energy; an increase in humidity shifts the energy balance at the glacier surface towards producing more melting than sublimation/evaporation. Finally, there is also a slight increase in temperature during the austral spring (Table 2), enhancing the sensible heat flux to the glacier surface. During the ensuing months of the wet season, there is a shift from net melting to net glacier storage.

While the annual hydrological balance describes a maximum volume of glacier storage loss during the transitional period between wet and dry seasons, the relative impact of this contribution to total stream discharge is largest during the dry season. The actual volume of glacier meltwater remains small relative to the magnitude of precipitation in this tropical setting. This distinction is important for understanding why the annual hydrographs from the streams leaving the glacier catchments match more closely the changes in monthly precipitation (Fig. 5).

\subsection{Annual meltwater contribution to stream flow}

While the hydrologic balance and the isotopic mixing model predict different percentages of annual glacier melt contribution to stream-flow leaving the glacier watersheds, the estimates are approximate and converge within a range cited in other studies. The net volume loss of glacier storage calculated from the annual hydrological balance amounts to about $35 \%$ of the mean monthly discharge for both of these glaciers (Table 3). This estimate is close to that from Glaciar Chacaltaya in tropical Bolivia, where complete disappearance of the glacier would reduce average annual stream discharge by $30 \%$ (Francou and others, 2000). The isotopic mixing-model estimates span a larger range, showing that the glacier ice melt contributes $23-54 \%$ of proglacial lake-discharge volume over the annual cycle. This reflects the variance in the monthly isotope value of precipitation used in the mixing model, which was only averaged over the years 1995-97. Yet the upper range of results are still similar to those from an earlier mass-balance study of Glaciar Yanamarey, citing a 50\% contribution to average stream discharge (Hastenrath and Ames, 1995). Therefore, considering the different methods and expected range of variation, an average estimate of about $40 \%$ is a reasonably conservative estimate of the contribution of glacier melt to the discharge from the glacier catchments.

The results of the annual hydrological balance of the glacier catchments can be combined with the insights gained from the hydrochemical mixing models in the Querococha watershed to estimate the overall glacier meltwater impact to the Río Santa. Assuming the mixing model shows a dilution effect downstream, with waters mixing conservatively, the glacier catchment discharge (YAN) seems to contribute about $30 \%$ of the stream-flow at Querococha (Q3). The well-separated end-member groups with two intermediate members seen on the Piper plot give confidence that the water leaving the glacier environment at YAN is diluted successively over distance to Q3. This 30\% contribution thus represents the impact of glacier watershed discharge on discharge from the Querococha watershed, having about 3\% glacier coverage. This is even less glacier coverage than the entire Callejon de Huaylas, which drains via the Río Santa to La Balsa, but presents a conservative analog for this larger drainage having about $8 \%$ glacier coverage (Table 1). Since the hydrological balance and isotopic mixing model of the glacier watersheds shows about $40 \%$ (up to $70 \%$ ) of the annual volume of the proglacial lake discharge is contributed by glacier melt, then the total volumetric impact of glacier melt to stream-flow at Querococha is about $12-20 \%$. Therefore, glacier meltwater can be conservatively estimated to provide at least $10 \%$ of the annual discharge volume to the Río Santa, with larger relative contributions in the dry season.

\subsection{Impact of tropical glacierized area on regional runoff}

The greater relative contribution of glacier melt in the dry season underlies the role of glaciers as "buffers" to the 
regional hydrology, an observation made for glaciers worldwide (Young, 1982; Röthlisberger and Lang, 1987; Chen and Ohmura, 1990; Kuhn and Batlogg, 1998). Glaciers hold precipitation in storage and compensate stream-flow in dry periods by providing meltwater (e.g. Fountain and Tangborn, 1985). While all the larger tributary streams of the Río Santa have annual hydrographs closely correlated to precipitation, those watersheds with a greater percentage of glacierized area display less variability in the magnitude of discharge between the wet and dry seasons (Figs 2 and 10a). As the glaciers in the watersheds shrink, the contrast between wet- and dry-season stream discharge will become greater, since there will be less glacierized area to store the concentrated precipitation at the height of the wet season, and less ice melt to buffer the low flows when precipitation decreases in the dry season.

There is a noteworthy contrast in the way these tropical glaciers influence stream discharge compared to those at higher latitudes. Larger percentages of glacierized area in watersheds tend to accompany higher levels of the specific discharge from streams in both the Cordillera Blanca (Fig. 10b) and the European Alps (Kuhn and Batlogg, 1998). However, when the ratio of maximum monthly discharge to mean monthly discharge $(\max Q /$ mean $Q)$ is regressed against the percentage of glacierized area for the same streams, the slope of the line is negative (Fig. 10c), opposite that shown for glacierized watersheds in the Alps, which has a positive slope of identical magnitude. This implies that maximum discharge in streams of the Cordillera Blanca tends to be relatively more mitigated by increased mean discharge with progressively greater glacierized area. One possible explanation for this difference is that climate affects seasonal glacier melt differently in the two regions. Tropical glacier melt moderates the contrasts of a very strong seasonal precipitation regime, while mid-latitude glaciers are exposed to greater temperature seasonality, and are less able to moderate extremes in runoff. Seasonal glacier melting in the mid-latitudes thus tends to increase the amplitude of runoff variations, while meltwater from tropical glaciers smooths the seasonal variation of runoff (Kaser and Osmaston, 2002).

\section{GONCLUSIONS}

This year-long case study of Peruvian glacier hydrology and hydrochemistry has revealed four main points that should be considered in future investigations involving more detailed energy-balance and runoff measurements.

1. The annual maximum glacier melt occurs during the austral spring for the glaciers in the Cordillera Blanca, Peru. Stream discharge from glacierized watersheds reaches a maximum in this season as a result of the enhanced melt. As glacier-mass changes are evaluated in relation to global climate changes (Oerlemans, 1994; Haeberli and others, 1999; Dyurgerov and Meier, 2000), and in relation to changes peculiar to tropical highlands (Diaz and Graham, 1996; Thompson, 2000; Vuille and Bradley, 2000), special attention should be paid to changes occurring during this spring season when glaciers are most sensitive to melting.

2. A significant amount of annual stream discharge to the Río Santa that drains the Cordillera Blanca is supplied by melting glacier ice. At least one-third of the water discharging from the glacier watersheds over the hydro- logical year comes from glacier melt. The relative melt proportion of stream discharge is greatest during the dry season, and also diminishes downstream from the glacier as precipitation runoff and ground-water discharge are mixed into the streams. Nevertheless, a hydrochemical mixing model of the lake Querococha watershed conservatively estimates that at least $10 \%$, and potentially as much as $20 \%$, of the Río Santa discharge in the Callejon de Huaylas comes from melting glacier ice that is not replenished by annual precipitation.

3. Glacierized watersheds of the Cordillera Blanca feature enhanced annual discharge and less variable runoff than non-glacierized streams. The degree of glacierization is directly related to the magnitude of these effects; as the percentage of glacierized area within a watershed increases, specific discharge increases, the coefficient of variation in discharge decreases, and the ratio of maximum discharge to mean discharge decreases (Fig. 10). While the former two of these characteristics are consistent with other glacier watersheds worldwide, the trend in maximum to mean discharge ratio is opposite those of higher northern latitudes, and implies a different response to seasonal climatic forcing.

4. With continued glacier recession, stream discharge is likely to decrease and become more variable, with larger volumes during the wet season and smaller amounts in the dry season. This has important implications for water resource management in this developing nation where glaciers have been receding throughout the past century, amplifying stream discharge as they melt. Progressive deglaciation has been observed over the past century (Kaser and Osmaston, 2002), even as temperatures have risen by $\sim 0.3 \mathrm{~K}$ per decade (Vuille and Bradley, 2000). Rivers like the Río Santa have had discharge augmented by glacier melt during a period of growth in infrastructure, featuring construction of HEP plants and urbanization (Barry and Seimon, 2000). Future public water supplies will decrease and become less consistent than the growing infrastructure has planned for, based upon the higher discharges of the past century.

\section{ACKNOWLEDGEMENTS}

The manuscript was refined by the careful editing of R. Naruse (Scientific Editor), with helpful comments from A. G. Fountain and an anonymous reviewer, for which we are grateful. Research was supported by the U.S. Fulbright Commission and the Geological Society of America. J. Gómez, J. "Pepe" Ames, C. Hopkinson, B. Seavey and the Peruvian National Institute of Natural Resources (INRENA) office in Huaraz are acknowledged for help with fieldwork, and A. Ames for logistical assistance. We also thank A. Rodriguez of Egenor SA for his help with historical stream-discharge data.

\section{REFERENCES}

Barry, R. G. and A. Seimon. 2000. Research for mountain area development: climatic fluctuations in the mountains of the Americas and their significance. Ambio, 29(7), 364-370

Chen, J. and A. Ohmura. 1990. Estimation of Alpine glacier water resources and their change since the 1870's. International Association of Hydrological Sciences Publication 193 (Symposium at Lausanne 1990-Hydrology in Mountainous Regions I: Hydrological Measurements; the Water Cycle), 127-135. 
Clark, I. D. and P. Fritz. 1997. Environmental isotopes in hydrogeology. New York, CRC Lewis.

Collins, D. N. 1978. Hydrology of an alpine glacier as indicated by the chemical composition of meltwater. Z. Gletscherkd. Glazialgeol., 13(1-2), 1977, 219-238.

Diaz, H. F. and N. E. Graham. 1996. Recent changes in tropical freezing heights and the role of sea surface temperature. Nature, 383(6596), 152-155.

Drever, J.I. 1997. The geochemistry of natural waters: surface and groundwater environments. Third edition. Englewood Cliffs, NJ, Prentice-Hall.

Dyurgerov, M. B. and M. F. Meier. 2000. Twentieth century climate change: evidence from small glaciers. Proc. Natl. Acad.Sci. U.S.A., 97(4), 1406-1411.

Fountain, A. G. and W. Tangborn. 1985. The effects of glaciers on streamflow variations. Water Resour. Res., 21(4), 579-586.

Fountain, A. G., P. Jansson, G. Kaser and M. Dyurgerov. 1999. Summary of the Workshop on Methods of Mass Balance Measurements and Modelling, Tarfala, Sweden August 10-12, 1998. Geogr. Ann., 81A(4), 461-465.

Francou, B., P. Ribstein, H. Sémiond, C. Portocarrero and A. Rodríguez. 1995a. Balances de glaciares y clima en Bolivia y Perú: impacto de los eventos ENSO. Bull. Inst. Fr. Etud. Andines (Lima), 24(3), 661-670.

Francou, B., P. Ribstein, R. Saravia and E. Tiriau. 1995b. Monthly balance and water discharge of an inter-tropical glacier: Zongo Glacier, Cordillera Real, Bolivia, $16^{\circ}$ S. F. Glaciol., 41 (137), 61-67.

Francou, B., E. Ramírez, B. Cáceres and J. Mendoza. 2000. Glacier evolution in the Tropical Andes during the last decades of the 20th century: Chacaltaya, Bolivia and Antizana. Ecuador. Ambio, 29(7), 416-422.

Haeberli, W., R. Frauenfelder, M. Hoelzle and M. Maisch. 1999. On rates and acceleration trends of global glacier mass changes. Geogr. Ann., 81A (4), 585-591

Hastenrath, S. and A. Ames. 1995. Diagnosing the imbalance of Yanamarey Glacier in the Cordillera Blanca of Peru. 7. Geophys. Res., 100(D3), 5105-5112.

Hastenrath, S. and P. D. Kruss. 1992. The dramatic retreat of Mount Kenya's glaciers between 1963 and 1987: greenhouse forcing. Ann. Glaciol., 16, 127-133.

He Yuanqing, W. H. Theakstone, Shi Yafeng and Yao Tandong. 2001. The isotopic record at an alpine glacier and its implications for local climatic changes and isotopic homogenization processes. F. Glaciol., 47(156), 147-151.

Hodgkins, R. 2001. Seasonal evolution of meltwater generation, storage and discharge at a non-temperate glacier in Svalbard. Hydrol. Processes, 15, $441-460$.

Hounslow, A. 1995. Water quality data-analysis and interpretation. Boca Raton, FL, Lewis Publishers.

Kaser, G. 1995. Some notes on the behavior of tropical glaciers. Bull. Inst. Fr. Étud. Andines (Lima), 24(3), 671-681.

Kaser, G. 1999. A review of the modern fluctuations of tropical glaciers. Global Planet. Change, 22(1-4), 93-103.

Kaser, G. and C. Georges. 1997. Changes of the equilibrium-line altitude in the tropical Cordillera Blanca, Peru, 1930-50, and their spatial variations. Ann. Glaciol., 24, 344-349.

Kaser, G. and H. Osmaston. 2002. Tropical glaciers. Cambridge, Cambridge University Press.
Kaser, G., A. Ames and M. Zamora. 1990. Glacier fluctuations and climate in the Cordillera Blanca, Peru. Ann. Glaciol., 14, 136-140.

Kuhn, M. and N. Batlogg. 1998. Glacier runoff in Alpine headwaters in a changing climate. International Association of Hydrological Sciences Publication 248 (Symposium at Meran/Merano 1998 - Hydrology, Water Resources and Ecology in Headwaters), 79-88.

Mosley, M. P. and A. I. McKerchar. 1993. Streamflow. In Maidment, D. R., ed. Handbook of Hydrology. New York, etc., McGraw-Hill Inc, 8.1-8.39.

Oerlemans, J. 1994. Quantifying global warming from the retreat of glaciers. Science, 264(5156), 243-245

Östling, M. and R.LeB. Hooke. 1986. Water storage in Storglaciären, Kebnekaise, Sweden. Geogr. Ann., 68A(4), 279-290.

Piper, A. M. 1944. A graphic procedure in the geochemicalinterpretation of water analyses. AGU Trans., 25, 914-923.

Ribstein, P., E. Tiriau, B. Francou and R. Saravia. 1995. Tropical climate and glacier hydrology: a case study in Bolivia. 7. Hydrol., 165(1-4), 221-234.

Röthlisberger, H. and H. Lang. 1987. Glacial hydrology. In Gurnell, A. M. and M. J. Clark, eds. Glacio-fluvial sediment transfer: an alpine perspective. Chichester, etc., John Wiley and Sons, 207-284.

Sharp, M., G. H. Brown, M. Tranter, I. C. Willis and B. Hubbard. 1995 Comments on the use of chemically based mixing models in glacier hydrology. 7. Glaciol., 41(138), 241-246.

Stichler, W. and U. Schotterer. 2000. From accumulation to discharge: modification of stable isotopes during glacial and post-glacial processes. Hydrol. Processes, 14(8), 1423-1438.

Tangborn, W.V., R. M. Krimmel and M. F. Meier. 1975. A comparison of glacier mass balance by glaciological, hydrological and mapping methods, South Cascade Glacier, Washington. International Association of Hydrological Sciences Publication 104 (Symposium at Moscow 1971 - Snow and Ice ), 185-196.

Thompson, L. G. 2000. Ice core evidence for climate change in the Tropics: implications for our future. Quat. Sci. Rev., 19(1-5), 19-35.

Vuille, M. and R. S. Bradley. 2000. Mean annual temperature trends and their vertical structure in the tropical Andes. Geophys. Res. Lett., 27(23), 3885-3888.

Wagnon, P., P. Ribstein, B. Francou and B. Pouyaud. 1999. Annual cycle of the energy balance of Zongo Glacier, Cordillera Real, Bolivia. 7. Geophys. Res., 104(D4), 3907-3923.

Wagnon, P., P. Ribstein, B. Francou and J. E. Sicart. 2001. Anomalous hea and mass budget of Glaciar Zongo, Bolivia, during the 1997/98 El Niño year. F. Glaciol., 47(156), 21-28.

Wilson, J., L. Reyes and J. Garayar. 1967. Geología de los cuadrangulous de Mollebamba, Tayabamba, Huaylas, Pomebamba, Carhuaz u Huari. Serv. Geol. Minería Bol. 16, 95.

Young, G. J. 1982. Hydrological relationships in a glacierized mountain basin International Association of Hydrological Sciences Publication 138 (Symposium at Exeter 1982-Hydrological Aspects of Alpine and High Mountain Areas), $51-59$.

MS received 4 February 2002 and accepted in revised form 9 February 2003 